\title{
Modification of poly(5,6-epoxy-L-norleucine) gives functional polypeptides with alternative side-chain linkages
}

\author{
Pesach Perlin, Wendell A. Scott and Timothy J. Deming
}

\section{Supporting Information}

\begin{abstract}
Abbreviations: degree of polymerization (DP), deionized (DI), room temperature (RT), equivalents (eq), molecular weight cutoff (MWCO), tetrahydrofuran (THF), potassium trifluoroacetate (KTFA), 1,1,1,3,3,3-hexafluoroisopropanol (HFIP), methanol (MeOH), (+/-) camphorsulfonic acid (CSA), diethyl ether $\left(\mathrm{Et}_{2} \mathrm{O}\right)$, dichloromethane (DCM), 1,8-diazabicyclo[5.4.0]undec-7-ene (DBU), tert-butyl hydroperoxide (TBHP), $N, N$-dimethylformamide (DMF), meta-chloroperbenzoic acid (mCPBA), $N, N$ dimethyl-cysteamine-carboxybetaine (CB-SH), $N$-carboxyanhydride (NCA), poly(L-homoallylglycine) $\left(\mathbf{G}^{\mathbf{H A}}\right)$, poly(5,6-epoxy-L-norleucine) (Enl), 2-methoxyethane-1-thiol modified poly(5,6-epoxy-Lnorleucine) ( $\left.\mathbf{m E G}_{\mathbf{1}}-\mathbf{E n l}\right), 2$-(2-methoxyethoxy)ethane-1-thiol modified poly(5,6-epoxy-L-norleucine) $\left(\mathbf{m E G}_{2}-\mathbf{E n l}\right), 2$-(2-methoxyethoxy)ethane-1-thiol modified poly(5,6-epoxy-L-norleucine sulfoxide) $\left(\mathbf{m E G}_{2}-\mathbf{E n l}^{\mathbf{O}}\right)$, 2-(2-ethoxyethoxy)ethane-1-thiol modified poly(5,6-epoxy-L-norleucine) (eEG $\mathbf{E}_{2}$-Enl), 2(2-ethoxyethoxy)ethane-1-thiol modified poly(5,6-epoxy-L-norleucine sulfoxide) ( $\left.\mathbf{e E G}_{\mathbf{2}} \mathbf{E}^{\mathbf{E n}} \mathbf{l}^{\mathbf{O}}\right)$, 2-[2-(2methoxyethoxy)ethoxy] ethanethiol modified poly(5,6-epoxy-L-norleucine) ( $\mathbf{m E G}_{\mathbf{3}}$-Enl), 2-[2-[2-(2methoxyethoxy)ethoxy]ethoxy] ethanethiol modified poly(5,6-epoxy-L-norleucine) ( $\left.\mathbf{m E G}_{\mathbf{4}}-\mathbf{E n l}\right), 1$ mercapto-11-hydroxy-3,6,9-trioxaundecane modified poly(5,6-epoxy-L-norleucine) (EG4-Enl), 1thioglycerol modified poly(5,6-epoxy-L-norleucine) (GL-Enl), $N, N$-dimethyl-cysteamine-carboxybetaine modified poly(5,6-epoxy-L-norleucine) (CB-Enl), rotary evaporation (rotovap), broad (br), doublet (d), doublet of triplets (dt), multiplet (m), singlet (s), quartet (q) triplet (t).
\end{abstract}


A)<smiles>C=CCC[C@H](NC(F)(F)F)C(C)=O</smiles><smiles></smiles>

B)

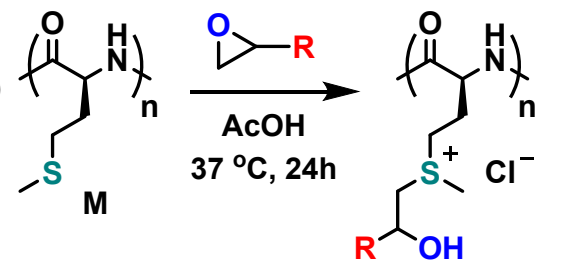

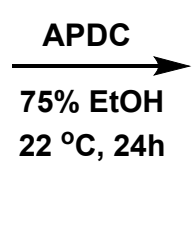<smiles>[R]C=CC[C@H](NC(C)(C)C)C(=O)CCSCC([R])O</smiles>

C)<smiles>COCCSCC[C@H]1NC(=O)OC1=O</smiles>

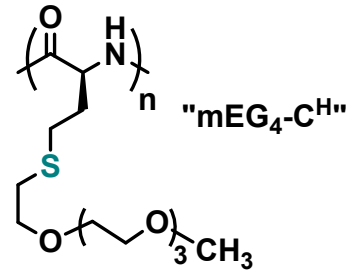

Scheme S1. Previously developed reactions for synthesis of functional thioether containing polypeptides. A) Preparation of thiol-ene conjugates, $\mathbf{R}-\mathbf{G}^{\mathbf{H A}}$, from poly(L-homoallylglycine), $\mathbf{G}^{\mathbf{H A}} \cdot{ }^{1}$ B) Preparation of poly(S-alkyl-L-homocysteine) conjugates, $\mathbf{R}-\mathbf{C}^{\mathbf{H}}$, via epoxide alkylation of poly(L-methionine), $\mathbf{M}$, and

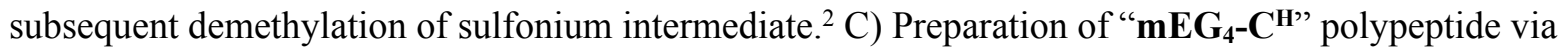
polymerization of functionalized NCA monomer. ${ }^{3} \mathrm{DMPA}=2$,2-dimethoxy-2-phenylacetophenone; $\mathrm{APDC}=$ ammonium pyrrolidinedithiocarbamate. 


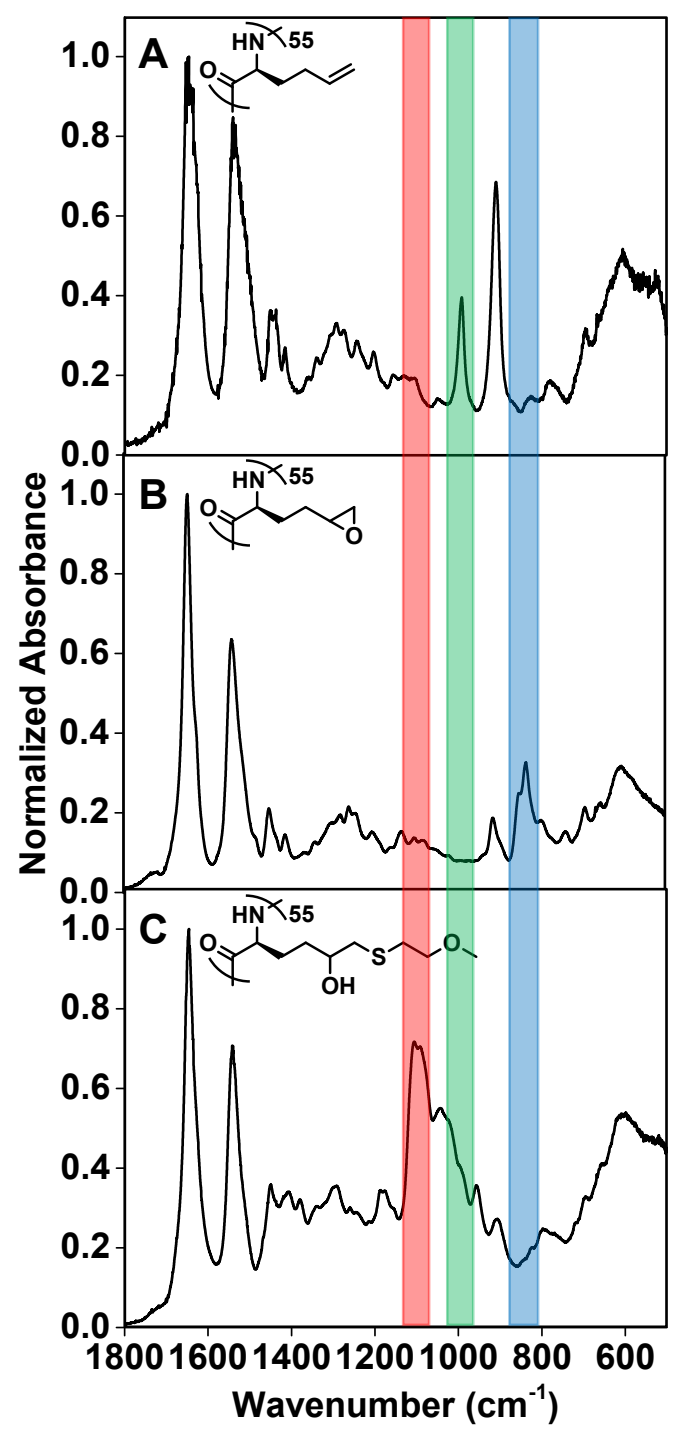

Figure S1. Normalized ATR-FTIR spectra of A) $\mathbf{G}^{\mathbf{H A}} \mathbf{5 5}$, B) $\mathbf{E n l}_{\mathbf{5 5}}$, and C) $\mathbf{m E G}_{\mathbf{1}}-\mathbf{E n l}_{\mathbf{5 5}}$. Band at $992 \mathrm{~cm}^{-1}$ (green) present in $\mathbf{G}^{\mathbf{H A}}{ }_{55}$ is consistent with an alkene C-H bend. Band at $835 \mathrm{~cm}^{-1}$ (blue) present in $\mathbf{E n l}_{\mathbf{5 5}}$ is consistent with an epoxide ring deformation. Band at $1102 \mathrm{~cm}^{-1}$ (red) present in $\mathbf{m E G}_{\mathbf{1}}-\mathbf{E n l}_{\mathbf{5 5}}$ is consistent with an ether C-O stretch. ${ }^{4,5}$ 


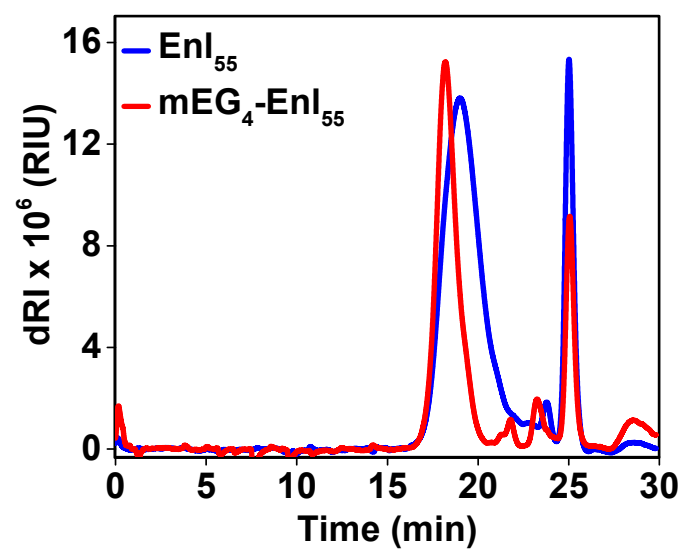

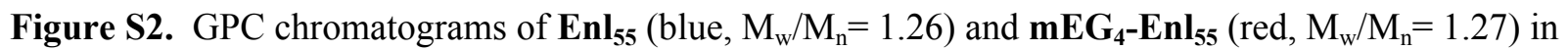
HFIP containing $0.5 \%(\mathrm{w} / \mathrm{w}) \mathrm{KTFA}$ at $10 \mathrm{mg} / \mathrm{mL}$. RIU = arbitrary refractive index units. Peaks after 23 min are due to salts and water in samples.

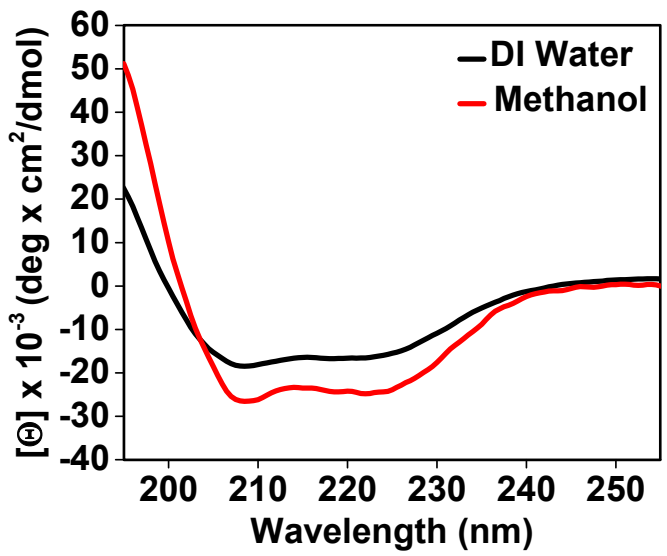

Figure S3. Circular dichroism spectra of $\mathbf{m E G}_{\mathbf{2}}-\mathbf{E n l}_{\mathbf{5 5}}$ collected at $0.1 \mathrm{mg} / \mathrm{mL}, 2{ }^{\circ} \mathrm{C}$ in DI water (black, $50 \% \alpha$-helix) or methanol (red, $72 \% \alpha$-helix). 


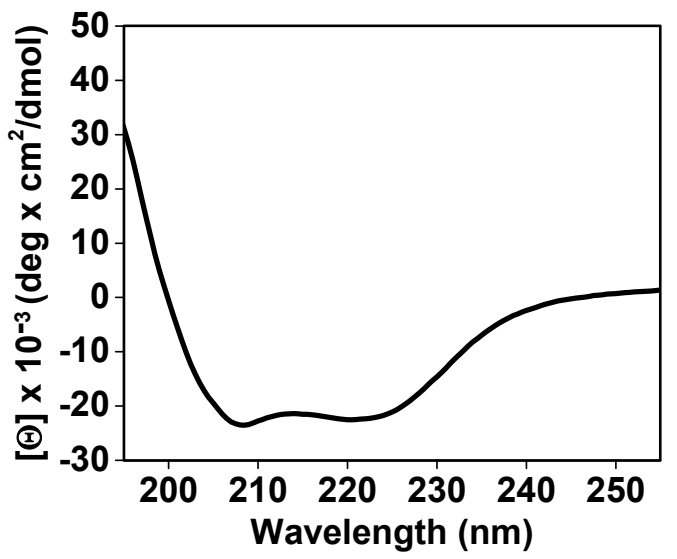

Figure S4. Circular dichroism spectrum of GL-Enl 5 in DI water at $0.1 \mathrm{mg} / \mathrm{mL}, 20{ }^{\circ} \mathrm{C}$.

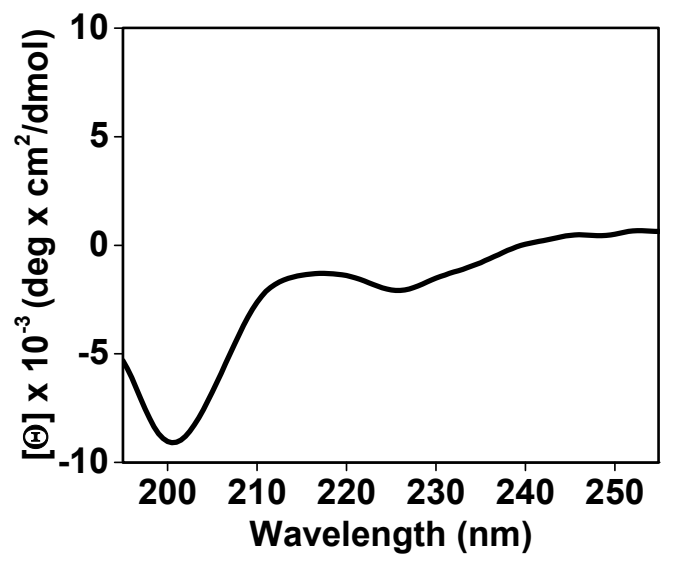

Figure S5. Circular dichroism spectrum of CB-Enl ${ }_{55}$ at $\mathrm{pH}$ 2. Polypeptide was dissolved at $0.1 \mathrm{mg} / \mathrm{mL}$ in an aqueous buffer containing $100 \mathrm{mM}$ phosphate and $10 \mathrm{mM}$ Tris, and the $\mathrm{pH}$ was adjusted using $0.1 \mathrm{M}$ $\mathrm{HCl}$. 


\section{Thiol Syntheses}<smiles>COCC[OH2+]</smiles>

2-methoxyethyl 4-methylbenzenesulfonate. This compound was synthesized by modification of a synthesis for a related molecule. ${ }^{1} \mathrm{H}_{2} \mathrm{O}(7.00 \mathrm{~mL})$ was added to 2-methoxyethanol (2.26 g, $\left.29.7 \mathrm{mmol}\right)$ and $\mathrm{NaOH}$ (2.37 g, $59.4 \mathrm{mmol})$. Tosyl chloride (5.95 g, $31.2 \mathrm{mmol})$ was dissolved in THF (7.00 mL) and added dropwise over ice with stirring. The reaction was let warm to ambient temperature overnight. Diethyl ether $(14.0 \mathrm{~mL})$ was then added to the reaction and the mixture was taken up into a separatory funnel and partitioned. The aqueous layer was washed with diethyl ether $(3 \times 3.50 \mathrm{~mL})$ then the combined organic fractions were washed with $\mathrm{H}_{2} \mathrm{O}(3 \times 14.0 \mathrm{~mL})$. The organic layer was dried with anhydrous sodium sulfate, decanted and evaporated to dryness to give the product as a clear oil (4.64 $\mathrm{g}$, $69 \%$ yield). ${ }^{1} \mathrm{H} \mathrm{NMR}\left(400 \mathrm{MHz}, \mathrm{CDCl}_{3}, 25{ }^{\circ} \mathrm{C}\right): \delta 7.80(\mathrm{~d}, \mathrm{~J}=8.3 \mathrm{~Hz}, 2 \mathrm{H}), 7.34(\mathrm{~d}, \mathrm{~J}=8.0,2 \mathrm{H}), 4.18-$ $4.13(\mathrm{~m}, 2 \mathrm{H}), 3.60-3.54(\mathrm{~m}, 2 \mathrm{H}), 3.30(\mathrm{~s}, 3 \mathrm{H}), 2.44(\mathrm{~s}, 3 \mathrm{H})$.<smiles>COCC[GeH3]</smiles>

2-methoxyethanethioacetate. This compound was synthesized by modification of a synthesis for a related molecule. ${ }^{1}$ 2-methoxyethyl 4-methylbenzenesulfonate $(2.04 \mathrm{~g}, 8.86 \mathrm{mmol})$ and potassium thioacetate $(1.26 \mathrm{~g}, 11.1 \mathrm{mmol})$ were dissolved in a round bottom flask containing acetone $(54.0 \mathrm{~mL})$. A reflux condenser was added and the reaction was stirred vigorously overnight at $50{ }^{\circ} \mathrm{C}$. Solvent was removed via vacuum and the resulting mixture was dissolved in a biphasic mixture of $16.0 \mathrm{~mL} \mathrm{DCM}$ and $16.0 \mathrm{~mL} \mathrm{H} \mathrm{H}_{2} \mathrm{O}$, taken up into a separatory funnel, and partitioned. The aqueous layer was washed with $2 \mathrm{x}$ 16.0 $\mathrm{mL}$ DCM and combined organics were washed with $6.0 \mathrm{~mL}$ brine. The organic layer was dried with anhydrous sodium sulfate, decanted, and evaporated to dryness to give the product as a yellow oil ( 0.370 g, 31\% yield). ${ }^{1} \mathrm{H}$ NMR (400 MHz, $\left.\mathrm{CDCl}_{3}, 25{ }^{\circ} \mathrm{C}\right): \delta 3.51(\mathrm{t}, \mathrm{J}=6.3 \mathrm{~Hz}, 2 \mathrm{H}), 3.36(\mathrm{~s}, 3 \mathrm{H}), 3.09(\mathrm{t}, \mathrm{J}=$ $6.2 \mathrm{~Hz}, 2 \mathrm{H}), 2.34(\mathrm{~s}, 3 \mathrm{H})$.

\section{-o $\Upsilon^{\mathrm{SH}}$}

2-methoxyethanethiol. Adapted from a procedure for deprotection of a related molecule. ${ }^{6}$ Methanol $(7.50 \mathrm{~mL})$ and conc. $\mathrm{HCl}(0.600 \mathrm{~mL})$ were added to a sealed pressure tube containing 2 methoxyethanethioacetate $(0.320 \mathrm{~g}, 2.38 \mathrm{mmol})$. The reaction mixture was stirred at $100{ }^{\circ} \mathrm{C}$ for 3 hours. The reaction was let cool to ambient temperature and then $\mathrm{H}_{2} \mathrm{O}(7.50 \mathrm{~mL})$ was added. This mixture was extracted with $3 \times 6.00 \mathrm{~mL}$ DCM. Combined organic extracts were then washed with $3 \times 6.00 \mathrm{~mL} \mathrm{H}_{2} \mathrm{O}$ and $1 \times 6.00 \mathrm{~mL}$ brine, dried with anhydrous sodium sulfate, decanted, and the solvent removed under 
partial vacuum $\left(30^{\circ} \mathrm{C}, 400 \mathrm{mbar}\right)$ to give the product as a yellow oil ( $0.200 \mathrm{~g}, 95 \%$ yield $)$. Spectral data agreed with previously published results. ${ }^{7}$

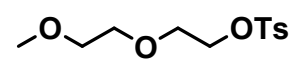

2-(2-methoxyethoxy)ethyl 4-methylbenzenesulfonate. The procedure for the synthesis of 2-

methoxyethyl 4-methylbenzenesulfonate was followed. Diethylene glycol monomethyl ether (5.1 g) was used to prepare the product, obtained as a clear oil (9.00 g, 77\% yield). ${ }^{1} \mathrm{H}$ NMR (400 MHz, $\mathrm{CDCl}_{3}, 25$ $\left.{ }^{\circ} \mathrm{C}\right): \delta$ 7.81-7.75 (m, 2H), $7.33(\mathrm{dd}, \mathrm{J}=8.6 \mathrm{~Hz}, 0.60 \mathrm{~Hz}), 4.20-4.11(\mathrm{~m}, 2 \mathrm{H}), 3.71-3.43(\mathrm{br} \mathrm{m}, 6 \mathrm{H}), 3.33(\mathrm{~s}$, $3 \mathrm{H}), 2.43(\mathrm{~s}, 3 \mathrm{H})$.<smiles>COCCOCC[AsH3]</smiles>

2-(2-methoxyethoxy)ethanethioacetate. The procedure for the synthesis of 2-methoxyethanethioacetate was followed. 2-(2-methoxyethoxy)ethyl 4-methylbenzenesulfonate ( $8.97 \mathrm{~g})$ was used to prepare the product, obtained as a yellow oil (5.50 g, 94\% yield). ${ }^{1} \mathrm{H} \mathrm{NMR}\left(400 \mathrm{MHz}, \mathrm{CDCl}_{3}, 25{ }^{\circ} \mathrm{C}\right): \delta 3.65-3.49$ (br m, 6H), 3.34 (s, 3H), $3.10(\mathrm{t}, \mathrm{J}=6.5 \mathrm{~Hz}, 2 \mathrm{H}), 2.33$ (s, 3H).

\section{-OحO $\mathrm{N}$ SH}

2-(2-methoxyethoxy)ethanethiol. This compound was synthesized by modification of a synthesis for a related molecule. ${ }^{1}$ Methanol $(20.0 \mathrm{~mL})$ and conc. $\mathrm{HCl}(1.50 \mathrm{~mL})$ were added to a sealed pressure tube containing 2-(2-methoxyethoxy)ethanethioacetate $(2.02 \mathrm{~g}, 11.3 \mathrm{mmol})$. The reaction mixture was stirred at $100{ }^{\circ} \mathrm{C}$ for 3 hours. The reaction was let cool to ambient temperature and then $\mathrm{H}_{2} \mathrm{O}(20.0 \mathrm{~mL})$ was added. This mixture was extracted with 3x $15.0 \mathrm{~mL}$ DCM. Combined organic extracts were then washed with $3 \times 15.0 \mathrm{~mL} \mathrm{H}_{2} \mathrm{O}$ and $1 \times 15 \mathrm{~mL}$ brine, dried with anhydrous sodium sulfate, decanted, and evaporated to dryness to give the product as a yellow oil (1.18 g, 77\% yield). Spectral data agreed with previously published results. ${ }^{6}$

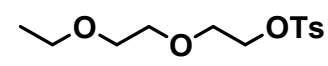

2-(2-ethoxyethoxy)ethyl 4-methylbenzenesulfonate. The procedure for the synthesis of 2-methoxyethyl 4-methylbenzenesulfonate was followed. Diethylene glycol monoethyl ether ( $2.02 \mathrm{~g}$ ) was used to prepare the product, obtained as a clear oil $(3.57 \mathrm{~g}, 82 \%$ yield $) .{ }^{1} \mathrm{H} \mathrm{NMR}\left(400 \mathrm{MHz}, \mathrm{CDCl}_{3}, 25^{\circ} \mathrm{C}\right): \delta 7.82-7.76$ (m, 2H), $7.33(\mathrm{~d}, \mathrm{~J}=8.0 \mathrm{~Hz}, 2 \mathrm{H}), 4.19-4.14(\mathrm{~m}, 2 \mathrm{H}), 3.71-3.66(\mathrm{~m}, 2 \mathrm{H}), 3.60-3.55(\mathrm{~m}, 2 \mathrm{H}), 3.53-3.45(\mathrm{~m}$, 4H), $2.44(\mathrm{~s}, 3 \mathrm{H}), 1.19(\mathrm{t}, \mathrm{J}=7.0 \mathrm{~Hz}, 3 \mathrm{H})$.

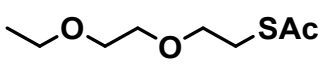


2-(2-ethoxyethoxy)ethanethioacetate. The procedure for the synthesis of 2-(2-

methoxyethoxy)ethanethioacetate was followed. 2-(2-ethoxyethoxy)ethyl 4-methylbenzenesulfonate $(2.25 \mathrm{~g})$ was used to prepare the product, obtained as a yellow oil (1.26 g, 84\% yield). ${ }^{1} \mathrm{H}$ NMR (400 $\left.\mathrm{MHz}, \mathrm{CDCl}_{3}, 25^{\circ} \mathrm{C}\right): \delta 3.66-3.45(\mathrm{br} \mathrm{m}, 8 \mathrm{H}), 3.10(\mathrm{t}, \mathrm{J}=6.5 \mathrm{~Hz}, 2 \mathrm{H}), 2.33(\mathrm{~s}, 3 \mathrm{H}), 1.21(\mathrm{t}, \mathrm{J}=7.0 \mathrm{~Hz}$, $3 \mathrm{H})$.

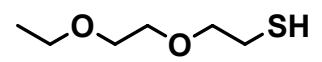

2-(2-ethoxyethoxy)ethanethiol. The procedure for the synthesis of 2-(2-methoxyethoxy)ethanethiol was followed. 2-(2-ethoxyethoxy)ethanethioacetate (1.25 g) was used to prepare the product, obtained as a clear oil (0.740 g, 76\% yield). ${ }^{1} \mathrm{H}$ NMR (400 MHz, $\left.\mathrm{CDCl}_{3}, 25^{\circ} \mathrm{C}\right): \delta 3.63-3.46(\mathrm{br} \mathrm{m}, 8 \mathrm{H}), 2.67(\mathrm{dt}, \mathrm{J}=$ $8.2 \mathrm{~Hz}, 6.5 \mathrm{~Hz}, 2 \mathrm{H}), 1.56$ (t, J = 8.2 Hz, 1H), 1.18 (t, J = 7.0 Hz, 3H). ${ }^{13} \mathrm{C} \mathrm{NMR}\left(100 \mathrm{MHz}, \mathrm{CDCl}_{3}, 25\right.$ $\left.{ }^{\circ} \mathrm{C}\right): \delta 72.9,70.3,69.7,66.6,24.2,15.1$.

\section{References}

1. Perlin, P.; Gharakhanian, E. G.; Deming, T. J. Chem. Commun. 2018, 54, 6196-6199.

2. Gharakhanian, E. G.; Deming, T. J. Chem. Commun. 2016, 52, 5336-5339.

3. Kramer, J. R.; Deming, T. J. J. Amer. Chem. Soc. 2014, 136, 5547-5550.

4. Bellamy, L. The Infra-Red Spectra of Complex Molecules. Chapman and Hall Ltd., London, 1975.

5. Wang, W.; Zhang, Q.; Zhang, B.; Li, D.; Dong, X.; Zhang, L.; Chang, J. Sci. Bull. 2008, 53, 1165-1170.

6. Keddie, D. J.; Grande, J. B.; Gonzaga, F.; Brook, M. A.; Dargaville, T. R. Org. Lett. 2011, 13, 6006-6009.

7. Tisato, F.; Maina, T.; Shao, L. R.; Heeg, M. J.; Deutsch, E. J. Med. Chem. 1996, 6, 1253-1261. 
NMR Spectra

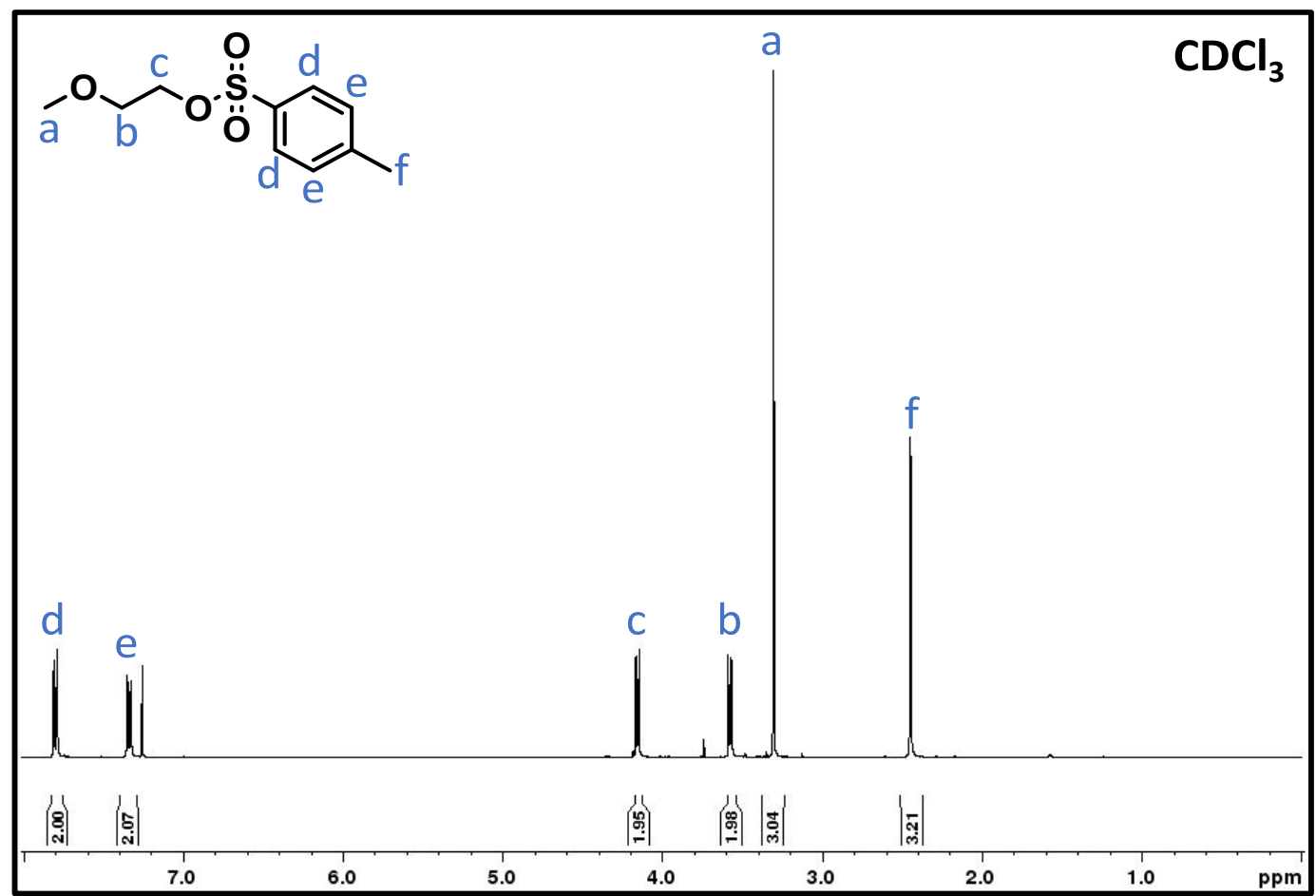



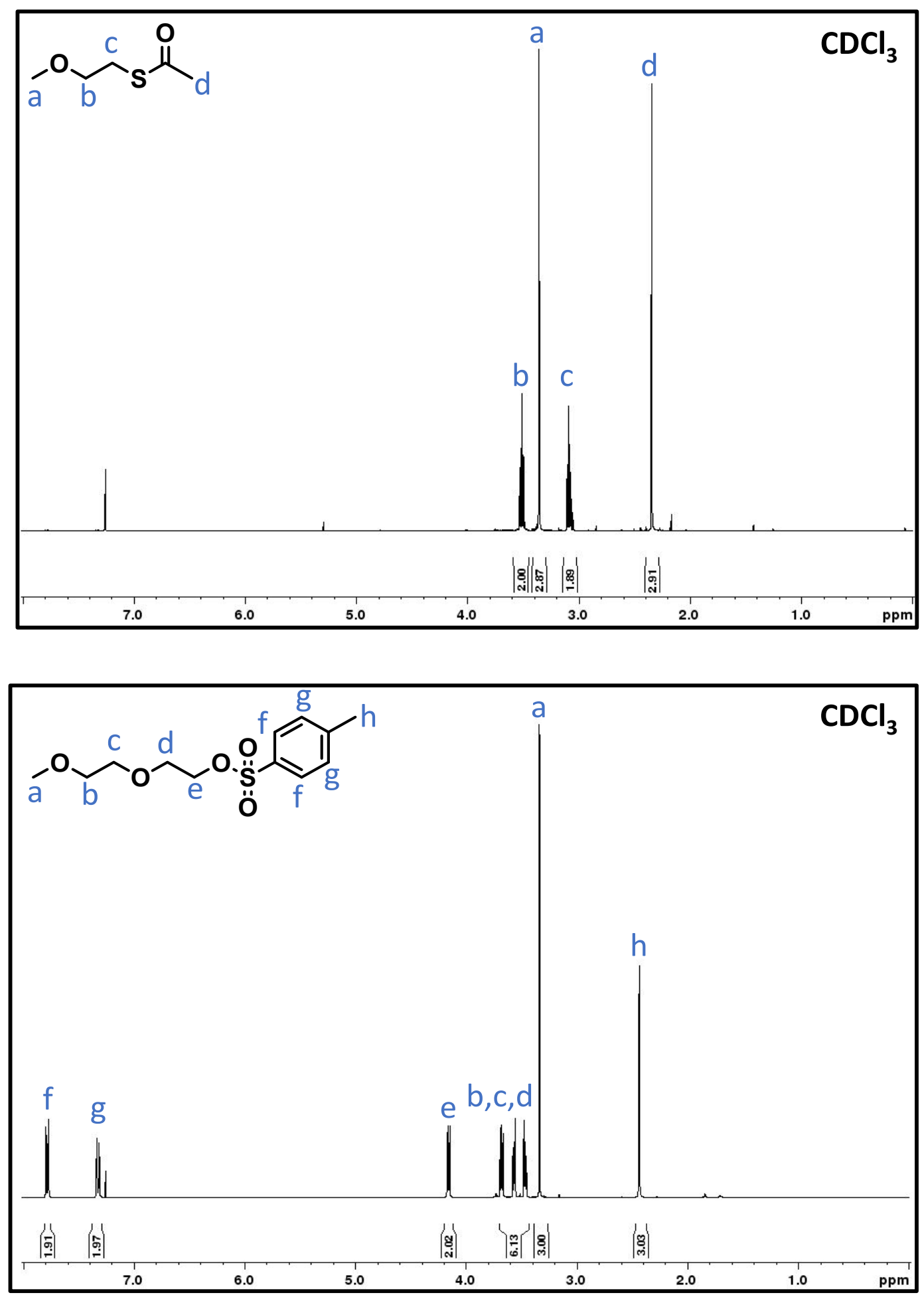

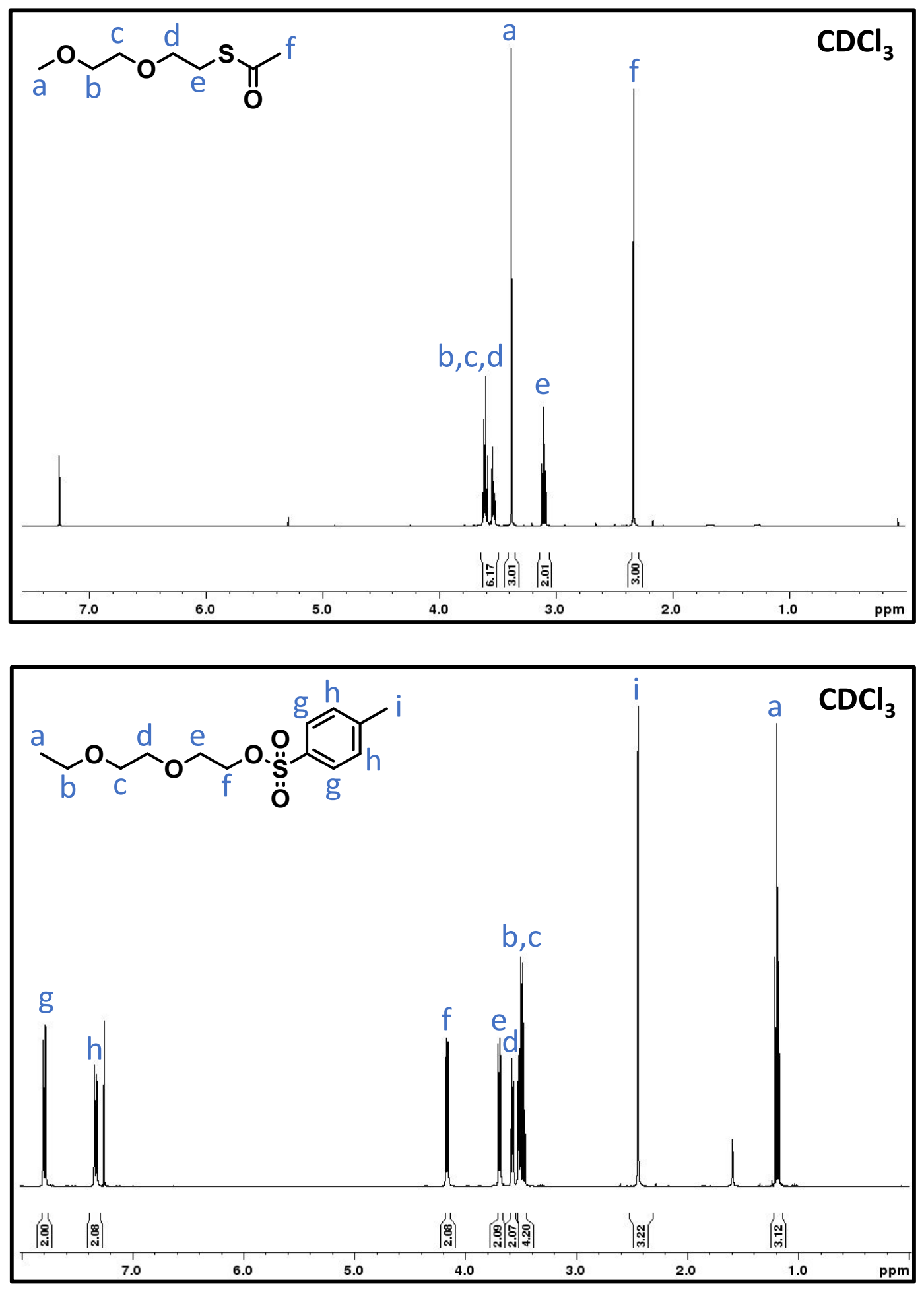

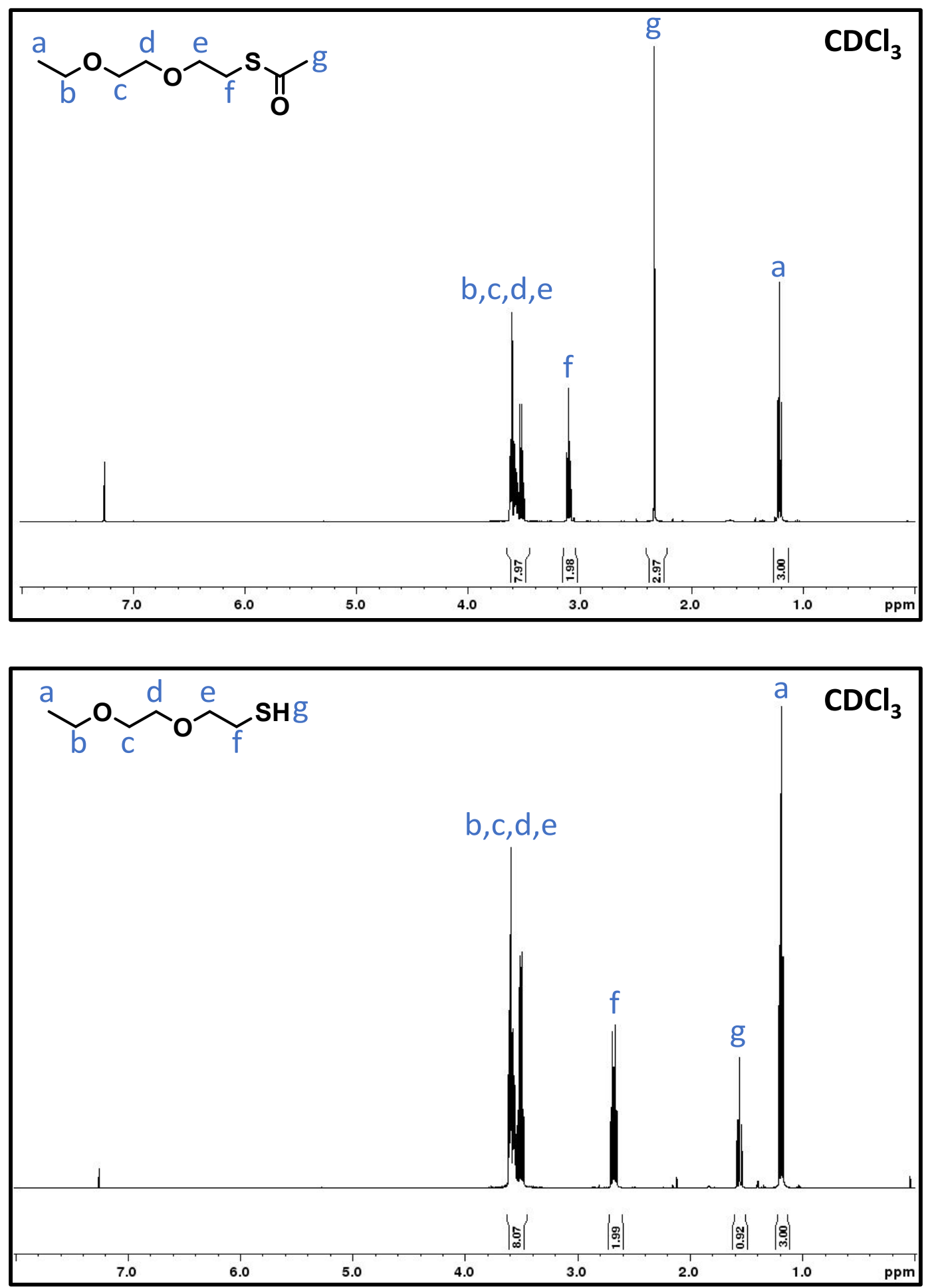

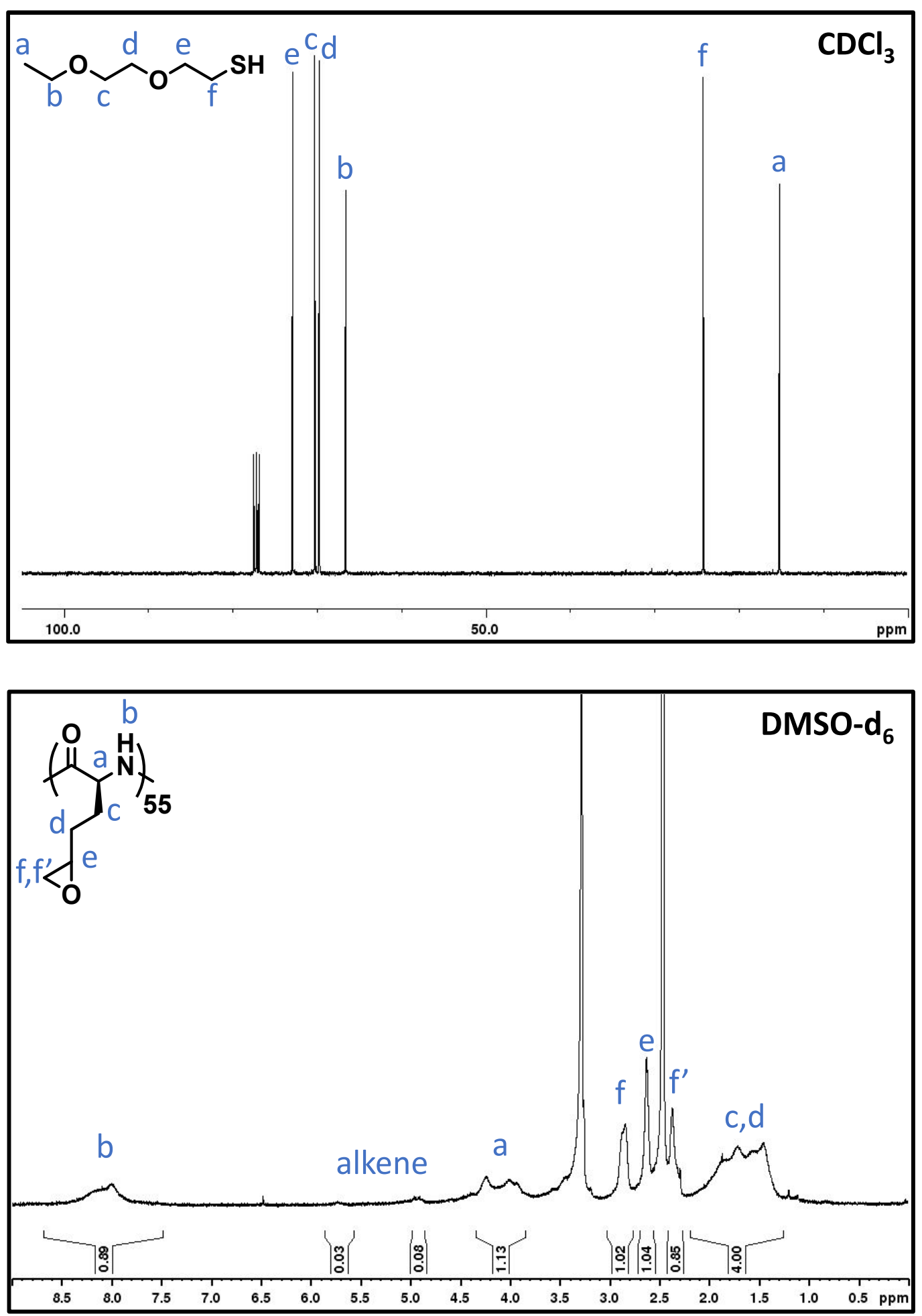

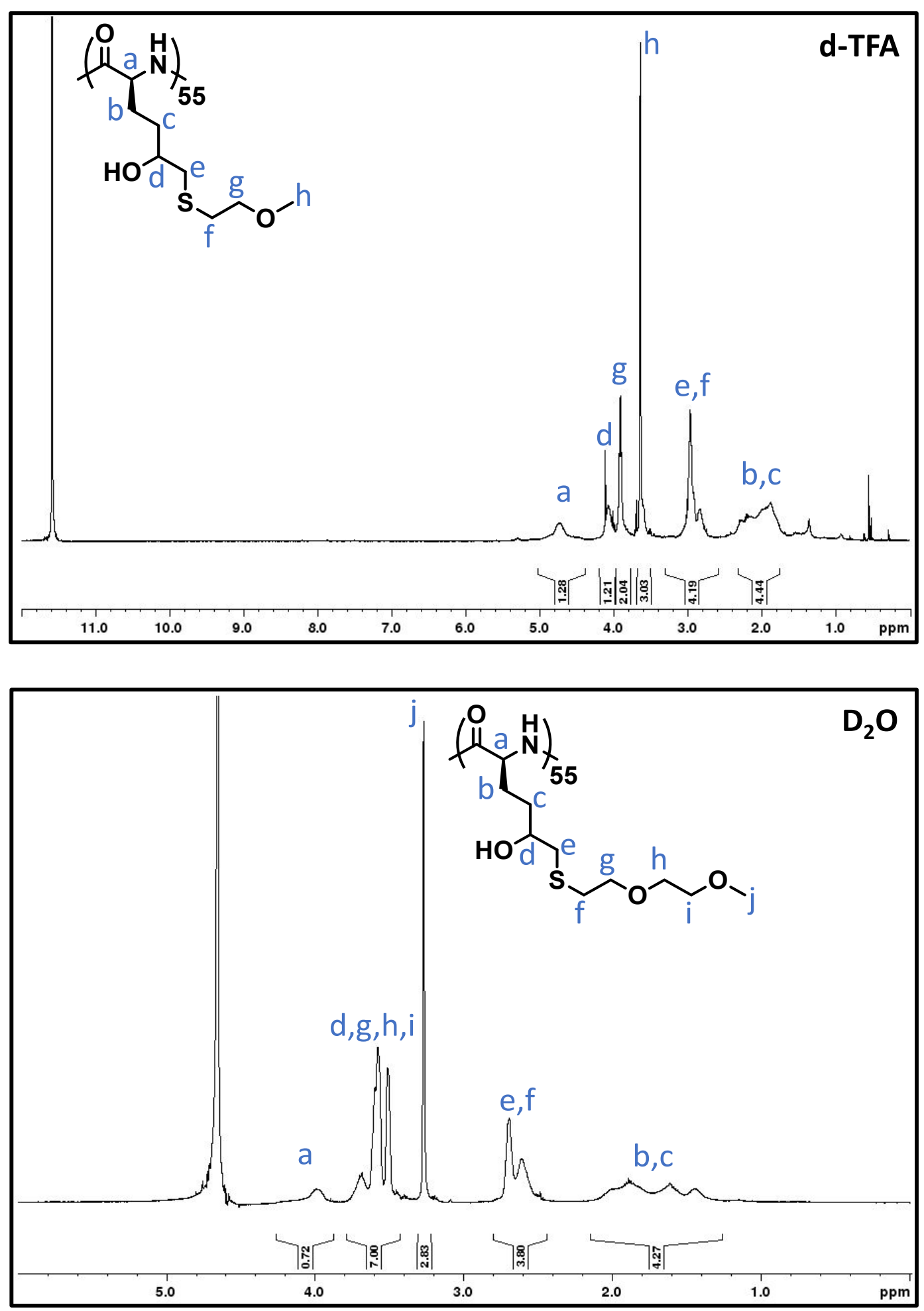

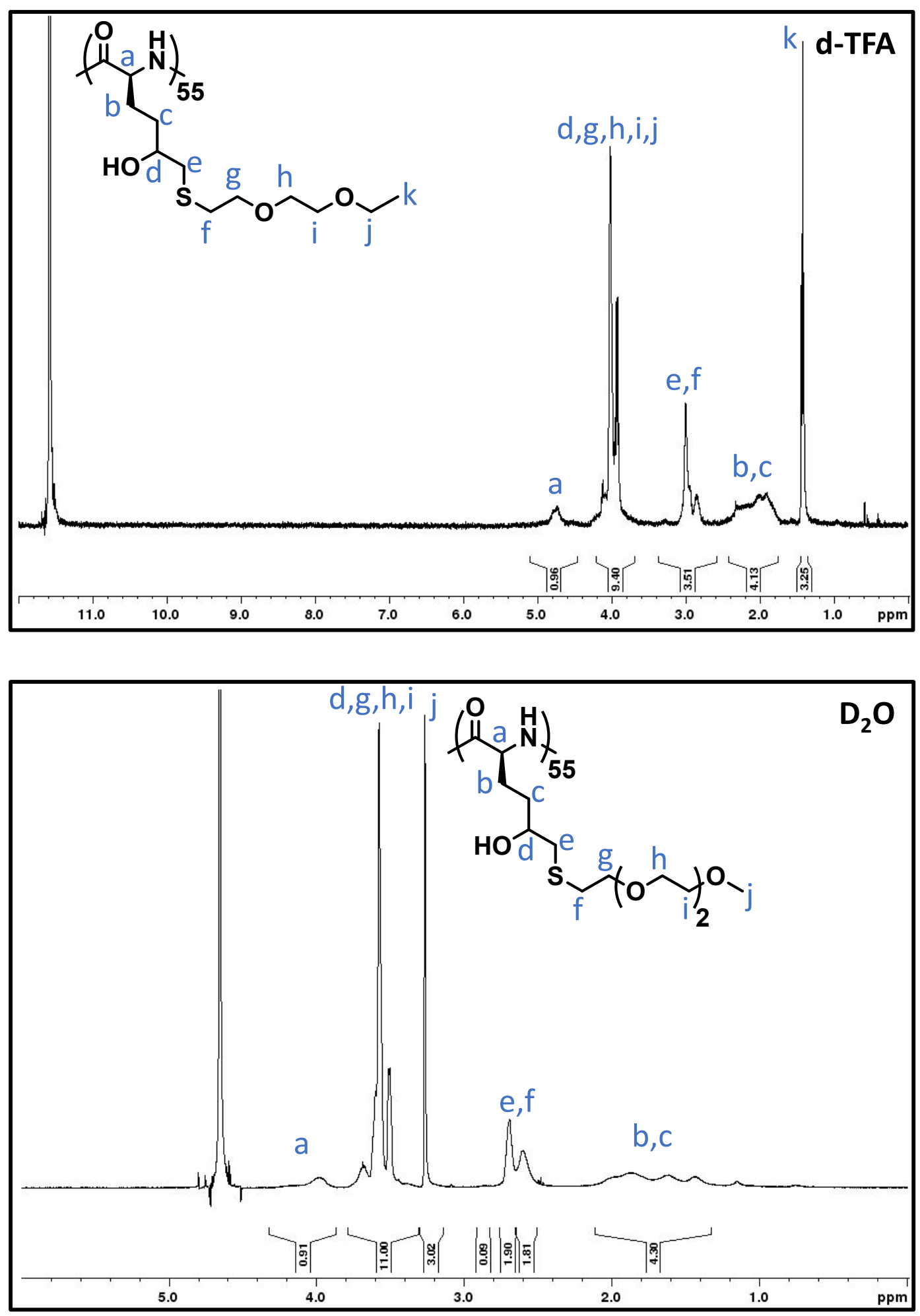

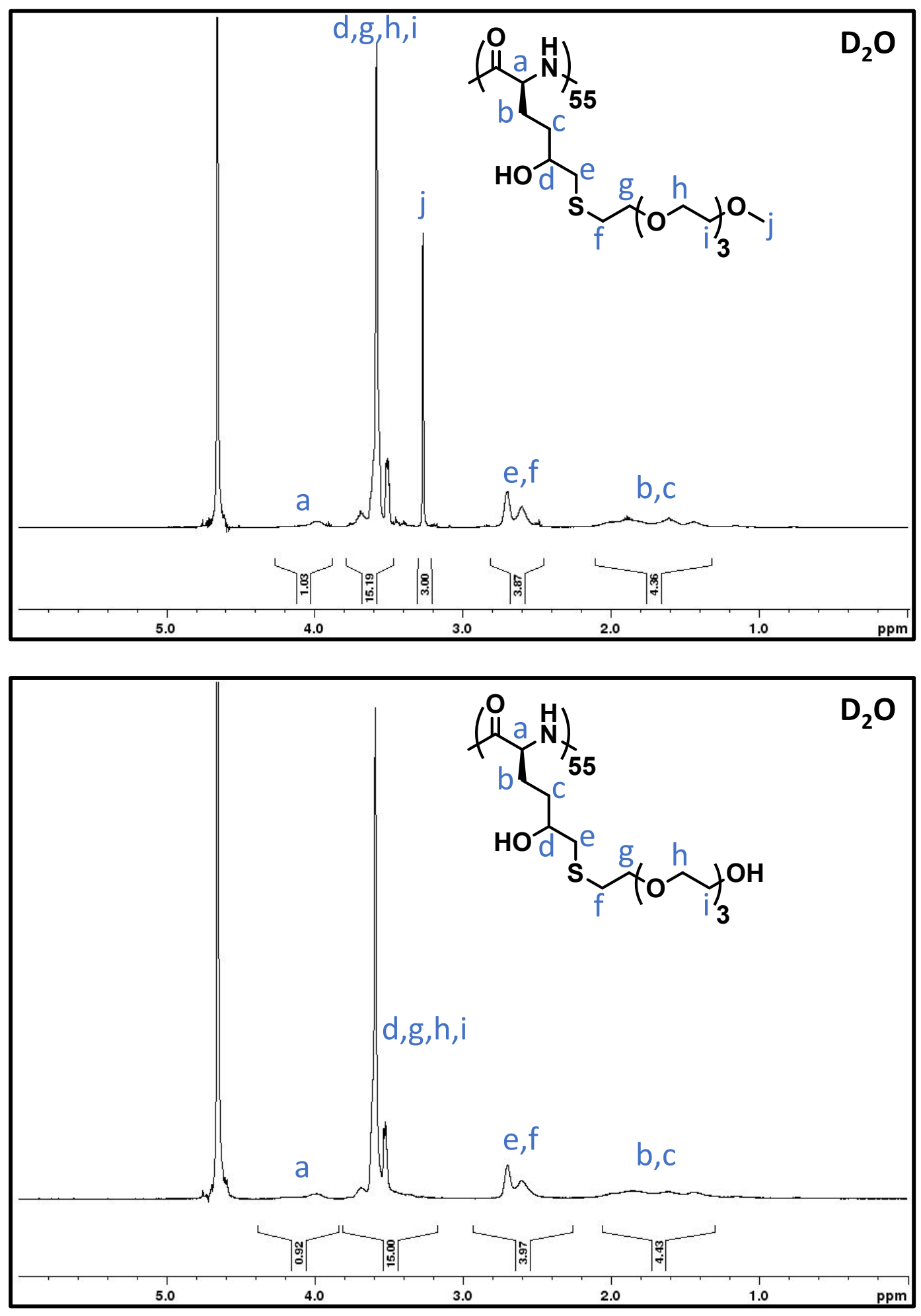

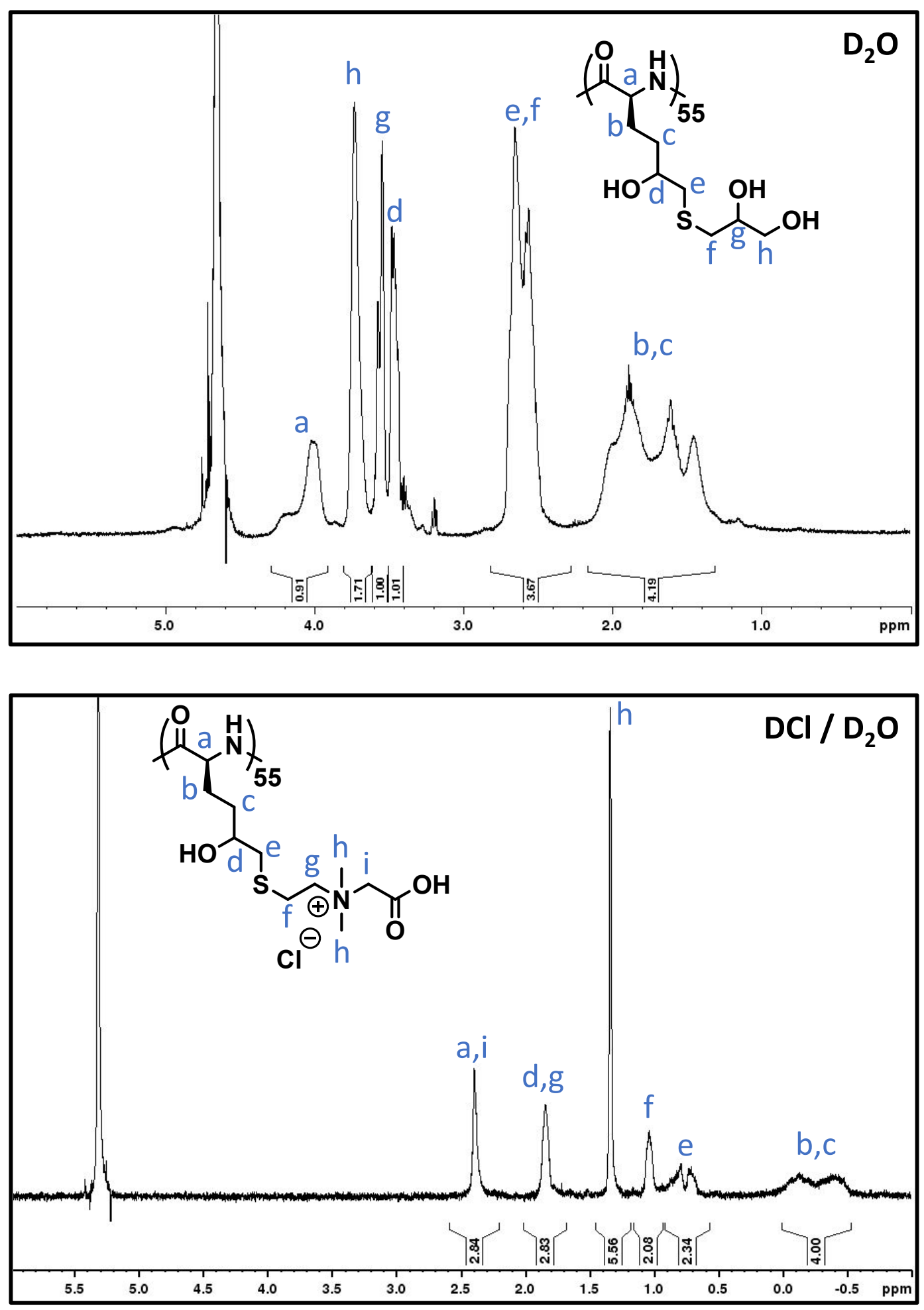

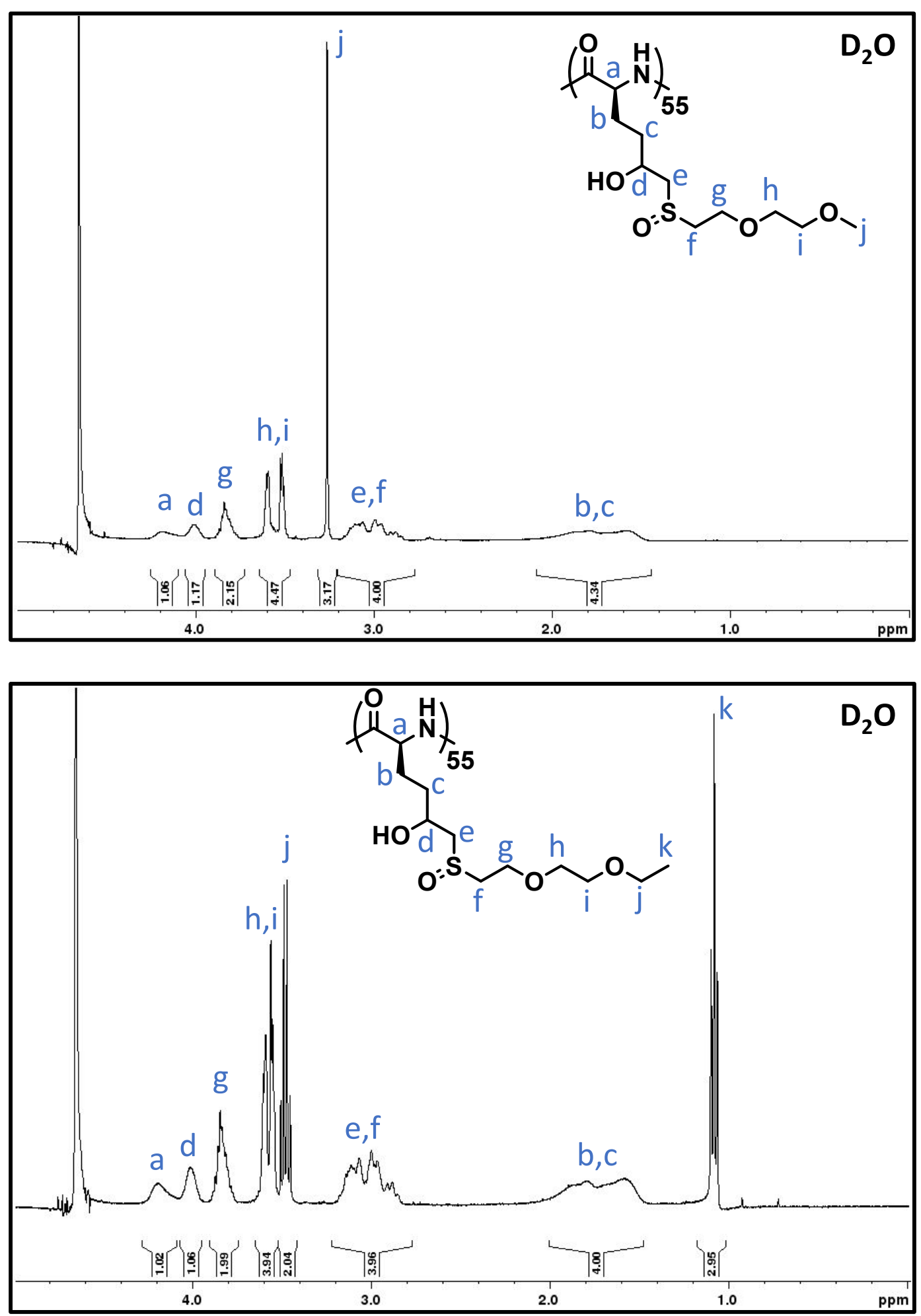